\title{
Limited detraditionalization of intimacy: \\ Growing socioeconomic differences in contraceptive use \\ at first intercourse in Italy
}

\author{
Emanuela Struffolino \\ Humboldt-Universität zu Berlin \\ Unter den Linden 6, 10099 Berlin, \\ Germany \\ emanuela.struffolino@wzb.eu
}

\author{
Hannah Zagel \\ Freie Universität Berlin \\ and \\ Humboldt-Universität zu Berlin \\ Unter den Linden 6, 10099 Berlin, \\ Germany \\ hannah.zagel@hu-berlin.de
}

Forthcoming in Advances in Life Course Research

\begin{abstract}
This paper investigates links between social inequality and reproductive behavior. It complements the extensive research on the stratification of young adults' life chances in education and the labor market by considering changes over time in the stratification of contraceptive use at first intercourse by parental background. We seek to understand detraditionalization trends in young people's sexually intimate behavior by investigating whether these trends were driven by particular social groups and how they were supported by policy initiatives. We study Italy from 1950-2006, which shows strong regional and socioeconomic disparities, and comparatively slow changes in religion and gender norms. Data from the "Survey on Italians' Sexual Behavior" (2006) and macro indicators on family planning centers are used. The findings show a steep increase in contraceptive use at first sexual intercourse over time, stratified by parental background, but only for condom use. We did not find that family planning centers intervened in these relationships.
\end{abstract}

Keywords: Contraceptive use, first intercourse, parental background, family planning centers, Italy 


\section{Introduction}

Romantic sexual intimacy across the life course changed profoundly in many advanced democracies throughout the past century, a trend supported by far-reaching developments in family planning technologies. Social theorists have described these trends as the detraditionalization of intimacy, arguing that intimate behavior, including sexuality and family formation, is increasingly separating from traditional social norms (Beck and Beck-Gernsheim, 2001; Beck-Gernsheim, 2002; Giddens, 1992). But while the changes mark historical shifts (Coontz, 2000; Lesthaeghe, 1998), detraditionalization is unlikely to have occurred universally. Critics have cautioned against assuming that changes in private lives are uniform across contexts (Therborn, 2004). There is also evidence for variations within countries. For example, cultural norms towards sexual behavior shifted unevenly across socio-economic and religious backgrounds (Treas, 2002). In this paper, we investigate stratified patterns in the detraditionalization of intimacy since the 1950 s in Italy. We look at changes in the empirical deviation of sexually intimate behavior from traditional norms among young people from different social backgrounds. In particular, we investigate how contraceptive use at first intercourse changed in a context of institutional liberalization over time, and how that change differed by parental education.

Detraditionalization of young people's intimacy implies that sexually intimate behavior increasingly decoupled from the pattern of sexual initiation within marriage (Giddens, 1992; Lesthaeghe, 1995; Treas, 2002). A growing emphasis on personal autonomy and the rejection of social control by the family and other institutions is characteristic of these changes (Caltabiano et al., 2020). In the traditional arrangement, the role of contraception was to control men's fertility before marriage, and women's fertility within marriage, after the desired number of 
children had been reached (Dalla Zuanna et al., 2005). Emerging contraceptive technologies made it easier to control fertility (Birdsall and Chester, 1987), and young people were increasingly able to realize intimate sexual behavior beyond the traditional setting. Contraceptive use at first intercourse thus represents a window into the prevailing degree of conformity with traditional norms at an important transition in individuals' sexuality trajectories (Carpenter, 2010).

Changes in whether and which contraceptive method young people use for their first intercourse indicates the nature of detraditionalization of intimate sexual behavior, but such trends have rarely been studied. Moreover, with narratives around the detraditionalization of intimacy commonly ignoring that it was not universal, we lack even a descriptive understanding of potentially divergent trends in contraceptive use at first intercourse across different social groups. This point echoes critiques of individualization and detraditionalization assumptions, which point to the continuing relevance of social background as a structuring mechanism in society (Breen, 1997; Goldthorpe, 2002; Platt, 2019). Research on contraceptive use across all age groups shows, for example, associations with high parental education (Manning et al., 2000), high own education (Buhr and Castiglioni, 2017) and favorable socioeconomic conditions during childhood (Brew et al., 2020).

In the case of contraceptive use at first intercourse, the extent to which liberalization aggravated or reduced stratification by social background is yet unknown. It is important to understand exactly how contraceptive behavior differentially deviates from traditional norms, because such change can have diverging implications. While it may lead to gains in personal autonomy and reproductive control, contraception outside the social norm may also expose individuals to stigmatization, and ineffective methods may have unintended outcomes with socio-economic 
consequences. We therefore look at changes in young people's contraceptive use at first intercourse by social background as a case for assessing stratified patterns in the detraditionalization of intimacy by addressing the following research question: How have patterns of contraceptive use at first intercourse developed for young people from different social backgrounds over a period of significant liberalization?

We examine trends in socioeconomic differences in contraceptive behavior at first intercourse between 1950 and 2006 among young people in Italy, relating the patterns to socio-historical developments across cohorts. There are three main reasons for using Italy as a case for analyzing the links between romantic sexual intimacy, social stratification and socio-historical context. First, Italy shows trends of institutional liberalization similar to many other countries, such as in family planning regulations from the late 1960s (Spinelli et al., 1993), the legalization of divorce in 1970, the drop of the ban on information about birth control in 1971, and the legalization of abortion in 1978. Second, despite these changes, Italy remains a country with traditional gender norms (OECD, 2017). These affect young people's contraceptive behavior, and could contribute to preserving traditional patterns. Third, there is persistently strong regional variation across Italy in terms of investment in health and education, living conditions, economic wellbeing, and demographic trends (SVIMEZ, 2019) that relate to persisting differences by socio-economic background. We exploit this variation to explicitly account for the social and institutional context in which individuals are embedded.

\section{Background}

In this section, we conceptualize contraceptive use at first intercourse as a case for the detraditionalization of intimacy, with a particular focus on socioeconomic differences. Based on the theoretical discussion, we derive hypotheses about how patterns of contraceptive use at first 
intercourse have developed over time and by social background, considering the specific setting of our study country Italy.

\subsection{Detraditionalization of intimate sexual behavior and contraception}

Family demographic patterns have shifted markedly across advanced democracies throughout the past century (Goldscheider et al., 2015). Marriage rates and first births have been delayed in the life course, cohabitation and non-marital childbearing have become more common, as have divorce and childlessness. For young people, sexual initiation and moving out of the parental home today occurs earlier in the life course and is more differentiated compared to the $1950 \mathrm{~s}$. These trends involved pronounced changes in romantic sexual intimacy on the individual level, which have prominently been described as consequences of modernization processes. An influential explanation featured in different theories is that the relevance of traditional norms for structuring people's behavior and ways of living declined (Beck and Beck-Gernsheim, 2001; Beck-Gernsheim, 2002; Giddens, 1992; Lesthaeghe, 1995, 1995). Hence, intimate relationships were less strongly dictated by traditional expectations about family demographic behavior, which was interpreted as the detraditionalization of intimacy (Gross, 2005). Sexuality, a central component of intimacy, was affected by the changes as it "became much more completely separated from procreation than before" (Giddens, 1991, p. 164) and "lost its extrinsic connections with traditions and ethics, as well as with the succession of the generations" (ibid.).

Cultural, technological, and medical developments underpin the changes in the meaning of first sexual intercourse; from being a crucial marker in the transition to adulthood to being one element in the extended period of adolescence. Intimacy among young people used to be strongly governed by traditional norms rooted in religious rules, including sex in marriage as standard with the purpose of reproduction for young women, and the double standard for young men 
(Giddens, 1992; Sagebin Bordini and Sperb, 2013). Traditionally, contraception tended to be condemned, and commonly practiced only after the desired number of children had been born within marriage. Traditional contraceptive methods such as coitus interruptus and monitoring fertile periods through measuring women's body temperature were most prevalent until the late 1990s (Dalla Zuanna et al., 2005).

With sexual liberalization, sex before marriage became more common (Bozon, 2003). Although nonmarital birth rates increased with these developments, first sexual intercourse before marriage should rather be understood as an indicator for the decoupling of childbearing intentions and sexuality, which was supported by medical developments (Lesthaeghe, 1995). Advances in contraceptive technologies were evident, especially from the 1960s onwards. Condoms became more widely available, and the pill was made accessible as a contraceptive method beyond medical purposes. Secularization trends allowed for these technologies to be more widely used, and for young people to pursue romantic sexual intimacy outside a traditionally prescribed family formation pathway (Giddens, 1992). While the range of contraceptive methods diversified over time, the pill and condoms have remained the most popular in terms of use (Johnson et al., 2013). In conclusion, young people increasingly sought to extend their autonomy in romantic sexual intimacy from the 1960 s by using the available methods to control their fertility and postpone pregnancy and childbearing.

\subsection{Stratified patterns of detraditionalization}

Despite the clear signs of the detraditionalization of intimacy, the shifts have likely not occurred uniformly across the social strata. Previous research has shown that patterns of contraceptive use are stratified by socioeconomic status, such as parental education (Manning et al., 2000), own education (Buhr and Castiglioni, 2017), employment (Pekkurnaz, 2019), and occupations (Layte 
et al., 2007). In all of these instances, lower socioeconomic status is generally associated with a reduced use of contraceptives.

In the following discussion, we use the labels of "more advantaged" and "disadvantaged" young people to refer to the respective socioeconomic status of their family of origin. Rather than attempting to decompose social background effects such as parental class, parental status and parental education (Bukodi and Goldthorpe, 2013), we follow research in the field of contraception in assuming that "more advantaged" young people have parents with overall higher levels of resources in terms of education, occupation and income than young people from “disadvantaged" backgrounds (Guzzo and Hayford, 2020). Because the different dimensions of social background are empirically highly correlated, we assume that either one reasonably reflects differences in young people's social positions in respect of potential differences in contraceptive use.

Empirical research on reproductive pathways provides evidence for drivers behind socioeconomic differences in contraceptive use. While differences in norms about parenthood and childbearing do not seem to explain socioeconomic differences in behavior, four intervening factors can be identified that affect the ability to adhere to those norms for young people from different socioeconomic backgrounds (Guzzo and Hayford, 2020): 1) knowledge about, comfort with, and trust in contraception and family planning service providers, 2) access to contraception, 3) efficacy, and 4) connection between norms and individual perceptions.

First, research suggests that in general the more informed young people are about contraception, the more likely they are to use contraceptives during first intercourse (Mauldon and Luker, 1996). However, more advantaged young people appear to have higher levels of contraceptive knowledge, as well as greater trust in and comfort with providers of contraception (Bell et al., 
2018; Lindberg and Maddow-Zimet, 2012; Sprecher et al., 2008). Second, access to contraception may be more restricted for disadvantaged young people than for more advantaged ones, because of health insurance coverage or regional availability of health care services (Bajos et al., 2004; Musick et al., 2009). Third, the belief in being able to shape one's own future, also termed efficacy (England, 2016), appears to be weaker among disadvantaged young people, which is associated with lower levels of contraceptive use (Reed et al., 2014). Fourth, disadvantaged young people are more often ambivalent about pregnancy and respond positively to unintended pregnancies more often than their more advantaged peers (Edin and Kefalas, 2005; Guzzo and Hayford, 2020). Based on these factors, we expect to find stratified trends in the detraditionalization of contraceptive use during first intercourse. Specifically, increases in contraceptive use during first intercourse over time should be less pronounced for disadvantaged young people than for more advantaged young people.

\section{Socio-historical context}

The socio-historical context in which young people live is a crucial factor in their contraceptive behavior. Several formal and informal institutions play a role in conveying information on sex and contraception, but also on social norms that prescribe what is acceptable or not and for whom (Billy et al., 1994; Borgoni and Billari, 2003). First, family planning regulations, such as divorce law and abortion law, provide the legal context for decisions over reproductive behavior. They set the opportunity structures that define individuals' options and alternatives. Policies have a similar function, but usually have redistributive aims in terms of levelling life chances. Contraception policies include service infrastructures for accessing information, contraceptive methods, and counselling support for young women. Such strategies gained momentum with the women's movement in the 1970s across European countries including Italy. 
Further, young people's contraceptive use has become a public health issue in many countries (Sprecher et al., 2008). In this context, contraception is discussed as a risk-aversion strategy. Public health campaigns and measures target young people to prevent sexually transmitted diseases (STD) and reduce incidents of early unintended pregnancy (Avery and Lazdane, 2008). The pill and condoms supported the realization of control over childbearing, especially for women. Increasingly since the HIV epidemic in the 1980s, public health institutions have promoted the use of contraceptives in order to protect against health risks associated with sexual intercourse, especially among young people. Condom use in particular protects against sexually transmitted diseases besides controlling unplanned pregnancy, while hormonal contraceptives such as the pill and intra uterine devices (IUDs) do not have this effect. Hormonal methods are commonly promoted to support women's personal autonomy (IPPFN, 2015). In a recent assessment of policies that grant women access to sexual and reproductive health and rights, Italy ranks lowest among 16 EU countries (alongside the Czech Republic and Romania) (IPPFN, 2015). This points to limited leverage of the reforms implemented since the $1970 \mathrm{~s}$. In the following, we characterize our study country Italy by outlining changes in the institutional settings, in norms and in demographic trends for sexual debut and contraception.

\subsection{Laws and policies in Italy}

Like many countries, the regulation of reproductive behavior in Italy has come a long way. The country moved from a severely restrictive period (up until the late 1960s), through a transformative period (late 1960s to early 1980s) to an ongoing more liberal period thereafter. Table 1 lists the most important changes in legislation and policies that set the stage for the first

and second contraceptive revolutions in Italy (Léridon, 1987), differentiating between these three periods. In the restrictive era, laws and policies protected the patriarchal family and there was no 
support for non-traditional sexual intimate behavior. The transformative period is characterized by the abrogation of laws limiting women's autonomy and freedom of choice in the family, and by legal changes that removed barriers to contraception. In the period to which we refer as liberal, access to a wide range of contraceptives has been virtually universal (in some cases under medical prescription), but the diffusion of family planning centers-which should guarantee access to knowledge about contraception and access to it - has been persistently lagging behind with respect to what may be expected from the legal regulations (see Figure A1 in Appendix A and IPPF (2015), Lauria et al. (2018)). Not just the diffusion has been slow even in more recent times, but large differences in the availability of family centers across regions have de facto given differential access to this key resource. This is likely to have penalized especially young people from less advantaged social background.

\begin{tabular}{|c|c|c|c|}
\hline Period & & \multicolumn{2}{|r|}{ Reforms } \\
\hline Restrictive & Before 1967 & & $\begin{array}{l}\text { Status quo: divorce and abortion illegal, shotgun wedding/honor killing } \\
\text { legal, family rights that leave the wife subject to the husband }\end{array}$ \\
\hline \multirow{10}{*}{ Transformative } & \multirow{10}{*}{$1967-1981$} & 1967 & Oral contraception for medical purposes \\
\hline & & 1970 & Legal divorce (Law 898) \\
\hline & & 1971 & End of ban on contraceptive advertising \\
\hline & & 1974 & Abrogative referendum on divorce (not passed) \\
\hline & & 1975 & Reform of family rights (Law 151) \\
\hline & & 1975 & Institutionalization of centers for family planning and health (Law 405) \\
\hline & & 1976 & Oral contraception extended to everyone \\
\hline & & 1978 & Decriminalization and legal access to abortion (Law 194) \\
\hline & & 1981 & Abrogative referendum on abortion (not passed) \\
\hline & & 1981 & Abolition of shotgun wedding/honor killing (Law 442) \\
\hline \multirow{3}{*}{ Liberal } & \multirow{3}{*}{ After 1981} & 2000 & $\begin{array}{l}\text { Emergency contraception with medical prescription (Authorization of } \\
\text { the Ministry of Health n.510 G.U. n. 238) }\end{array}$ \\
\hline & & 2004 & $\begin{array}{l}\text { Norms on assisted reproduction technology (Law 40): limits to ART for } \\
\text { specific populations and embryo protection model dissonant from Law } \\
\text { 194/1978. }\end{array}$ \\
\hline & & 2016 & $\begin{array}{l}\text { No medical prescription for emergency contraception (except for } \\
\text { minors) }\end{array}$ \\
\hline
\end{tabular}

Table 1. Socio-historical contexts and reforms

Besides family planning regulations, sex education governs young people's contraceptive use by providing knowledge about contraception. In Italy, the first proposal for the introduction of 
sexual education in schools as part of the curricula dates back to 1910, and it was followed by several other attempts (Rifelli and Ziglio, 1991). Up until today, none of the proposals have received sufficient support to be transformed into law, mostly owing to concerns that sex education would incentivize sexual activity among young people. Public health initiatives have been more successful, although admittedly insufficient (Donati et al., 2000; Ministero della Sanità, 1992). Even recently, pilot programs of sex education demonstrate a lack of basic knowledge of the biology of sexuality and contraception (Bogani et al., 2015).

Taken together, two competing hypotheses emerge from the considerations about socioeconomic differences in contraceptive behavior and institutional provision in Italy. First, it would be reasonable to expect that the diminishing institutional barriers to contraception might have led to smaller socioeconomic differences in contraceptive use over time, particularly in the liberal period (Hypothesis 1a). By contrast, the persistent lack of widespread provision of free contraceptives and the unequal diffusion of family planning centers and sex education across Italy gives reason to expect that socioeconomic differences have widened over time (Hypothesis 1b).

\subsection{Norms in Italy: The Church and the family}

A central institution of sexuality norms in Italy is the Roman Catholic Church. Most children born in Italy are christened in the Catholic Church. Their religious socialization extends across childhood and preadolescence as they receive Reconciliation and Communion at the age of 8-10 years and Confirmation at age 14-15 years. Moreover, curricula in public schools include Catholic religion classes held by teachers directly appointed by the Church. From the late 1960s, there has been a gradual reduction in the participation of young people in religious practices after receiving the Sacraments (Cesareo et al., 1995), but religious marriage remains very popular. For 
more recent cohorts, the family acts as the mediator of the Catholic percepts and dogmas, making indirect appearances in secularized everyday lives in the form of social norms and habits (Vignoli and Salvini, 2014).

Strong intergenerational ties and their links with family demographic behaviors are considered to be a central factor in the sluggish detraditionalization across generations in Italy (Dalla Zuanna and Micheli, 2006; Rosina and Fraboni, 2004). In comparison with other European countries, changes in family structures have been slow in Italy (Pirani and Vignoli, 2016), and changes in sexual behavior are no exception (Barbagli et al., 2010). Older generations are crucial in the reproduction of traditional gender roles (Farre and Vella, 2013; see for the US Moen et al., 1997), mainly by parents exerting pressure and discouraging their children from non-normative behavior during adolescence and beyond (Vignoli and Salvini, 2014). The transmission of family demographic norms and behavior differs across social groups. For example, traditional norms about marriage are more prevalent among women than men (Vignoli and Salvini, 2014), and family transitions occur in more traditional patterns for young people from lower than for those from higher socioeconomic backgrounds (Sironi et al., 2015).

The Catholic Church seems to have also slowed down the diffusion of safe contraceptive methods in Italy compared to other European countries. First, the territorial distribution of centers for family planning and health mirrors the patterns of votes in the referenda on divorce and abortion (Spinelli et al., 2000). Second, an extremely high proportion of medical doctors in Italy are conscientious objectors to abortion (between 65 and 95 percent across regions, with very little variation over time). We lack empirical evidence on the attitudes and behavior of family doctors and gynecologists concerning contraception and on whether conscientious objection is driven by religiosity. That means, whether objecting doctors would also proactively discourage the use of 
contraceptives remains an open question. However, there are indications for high barriers to contraception from local surveys (Volante et al., 1978) and qualitative studies and reports (Dalla Zuanna et al., 2005), which suggest that requests for subscriptions of the pill are sometimes not fulfilled, and individuals do not receive adequate information on contraception (IPPFN, 2015).

\subsection{Sexual debut and contraception in Italy}

In Italy, norms with respect to first sexual intercourse seem to persist, even among more recent cohorts of young adults (Billari and Mencarini, 2004; Ferrero Camoletto, 2014). Despite quantitative evidence on some convergence in sexual behavior, gendered sexual scripts persist in the narratives around first sexual intercourse. Over time, the median age at first sexual intercourse in Italy has changed moderately for men, decreasing from 18.5 to 17.5 for those born in the 1940s and 1980s respectively. For women the median age of sexual initiation was 22 for those born in the 1910s, 20 for those born in the 1950s, and 18.5 for those born in the $1980 \mathrm{~s}$ (Barbagli et al., 2010; Billari and Borgoni, 2002). For more recent cohorts of women, the age at first intercourse is equal to that of men only in regions in the Centre and North (Billari and Borgoni, 2002). In the past, first sexual intercourse for women occurred within a stable relationship and predominantly within marriage, but from the 1970s this was no longer the case. In fact, the sexual revolution took place at the same time as the increase in average age at marriage (22 years-old for those born in the 1950s, 27 years-old for cohorts born in the 1970s). However, unlike in northern and central Europe, Italy did not see strong increases in cohabitation or living alone (or with friends), so that young adults experienced a long sexually active period while living with their parents. This situation restrained the frequency of sexual intercourse (Castiglioni et al., 2001). 
Up until the 1970s, a uniform contraceptive model prevailed in Italy, with the great majority of individuals relying on coitus interruptus. This pattern relied on traditional sexuality norms. Indeed, most married couples used modern contraception only after reaching the planned number of children. According to the more conservative interpretation of Catholic doctrine, even traditional contraceptive methods such as coitus interruptus are considered illegitimate. However, its widespread diffusion even among older (and supposedly more traditional) cohorts suggests that the idea of "religious bricolage" or patchwork religion also applies to Italy (Garelli et al., 2003). As such, coitus interruptus remains widely practiced (Johnson et al., 2013). In 2006, among cohabiting and married couples 30 percent use the pill, 27 percent use the condom, and 30 percent use coitus interruptus (Barbagli et al., 2010). Data on 2013 show extreme stability in these trends: among 20-49 year-old women in a couple, 27 and 23 percent respectively always use the pill or the condom (ISTAT, 2017). Among those born in the 1980s, 47 percent use safe contraceptive methods and 23 percent use coitus interruptus during intercourse (Barbagli et al., 2010).

There are several limitations to the existing research on first sexual intercourse and contraception in Italy. In particular, most studies focus on single cohorts of individuals, and in the most recent case on university students (Caltabiano et al., 2006; Dalla Zuanna et al., 2019; Dalla Zuanna and Crisafulli, 2004), or rely on small qualitative samples (Camoletto, 2011; Ferrero Camoletto, 2014), or they consider multiple cohorts (Billari and Borgoni, 2002; Barbagli et al., 2010) but do not account for the interaction between the use of contraception and parental background. 


\section{Data and methods}

\subsection{Data}

We use data from the Survey on Italians' Sexual Behavior (“Indagine sulla Sessualità degli Italiani" ISI henceforth) on 3058 individuals aged 18-69 years old interviewed in $2006 .{ }^{1}$ The ISI collected information on a wide range of aspects related to sexual behavior and attitudes towards sex. The results are generalizable to the population using the post-stratification weighting scheme (Barbagli et al., 2010). 152 individuals (5\% of the initial sample) had not experienced first sexual intercourse when interviewed. Focusing on adolescence as a distinct phase in the life course, we restricted the sample to individuals who experienced first intercourse between and including the age of 10 and 24 (Sawyer et al., 2018): 95 had sex before the age of 10 or older than 24 (3.1\% of the initial sample). Finally, because 294 individuals have missing values on the dependent variable ( $9.6 \%$ of the initial sample), our final analytical sample contains 2,517 individuals (1,252 men and 1,265 women). ${ }^{2}$ After listwise deletion of missing cases on the independent variables and covariates (see Table 2 below), we are left with 2,483 valid cases.

\footnotetext{
${ }^{1}$ The Survey on Italians' Sexual Behavior - ISI (Indagine sulla Sessualità degli Italiani) was collected within the framework of a project (ex-40\%) financed by the Ministry of Education, University and Research MIUR in 2004 lead by University of Bologna, the University of Turin, University of Padua (P.I. Marzio Barbagli).

${ }^{2}$ Table A4 in Appendix A displays the distribution of the independent and control variables for those who have not experienced the first intercourse at the time of the interview and those who have missing values on the dependent variable. Comparing descriptively these samples with the analytical sample on the most important variables, we conclude that the excluded cases do not substantially differ from those included in the analyses. The overrepresentation of women among those who did not have sex for the first time at the moment of the interview is due to the young women from the more recent cohorts in the sample who still experience (on average) their sexual debut at a relatively later age compare to young men.
} 


\subsection{Variables and methods}

Our first dependent variable is a binary indicator for the use of any contraceptive methods at first sexual intercourse: condom, pill, or IUD. The second dependent variable, from which we aim to gain further insight into what drove changes in contraception, distinguishes between different types of contraception: condom or hormonal contraceptive (pill or IUD). The main independent variable is social background, which we operationalized with an indicator of parental education by adopting the standard dominance criterion as the highest education level among parents (at most lower secondary and at least upper secondary).

We estimate changes over time in the association between the two outcomes and parental education by interacting this latter with the socio-historical period when first intercourse occurred. The socio-historical period when first intercourse occurred is captured by a variable that distinguishes between those who experienced first sexual intercourse before 1967 (restrictive context), between 1967 and 1981 (transformative context) and after 1981 (liberal context) —see Table 1 for the time line of the introduction of reforms related to access to contraception and abortion.

To rule out the effect of contextual differences on the two outcomes, we exploit regional variation in the availability of centers for family planning and health across 20 regions over time $(0 ; 0.1$ $1 ; 1.1-3 ; 3.1-5 ; 5+$ per 10,000 women $15-49$ years old): we anchor this indicator to the year when

the respondent experienced first sexual intercourse. These data are retrieved from the Report of the Ministry on the implementation of the Law 194/1978 for the social protection of motherhood and legal abortion compiled (almost) every year from 1979. Descriptive distribution of centers for family planning and health across regions and over time (1979-2006) can be found in Figure A1 and Table A1 in Appendix A. More details on these data are reported in Appendix B. The 
cross-sectional nature of the data does not allow us to rule out the effect of other regional differences, so we further adjust the models for fixed-effects for the geographical macro-area of residence (the North-West, North-East, Center, South and Islands). Adding these context-related covariates to the model, that is family planning centers and geographical macro-area, serves the purpose of accounting for the variation in actual availability of health services related to contraception and of controlling for persisting differences in investment in health and education, living conditions, economic wellbeing, and demographic trends respectively. The inclusion of both indicators is necessary because differences in distribution of family planning centers does not overlap with traditional North-South differences across geographical macro-area, as displayed in Figure A1 in Appendix A.

All models are adjusted for: gender of the respondent, type of relationship with the sexual partner (not in a relationship, in a relationship, cohabitation/marriage) ${ }^{3}$, size of the city (up to 5,000 , $5,001-10,000,10,001-30,000,30,001-100,000,100,001-500,000,500000+)$, and age at first intercourse (min.10, max. 24, s.d. 2.61). Table 2 shows the distribution of the dependent and independent variables as well as controls in the analytical sample. The coefficients of interest are displayed as predicted probabilities (Long and Freese, 2014); Table A2 and A3 in the Appendix display the results from full models. ${ }^{4}$

\subsection{Robustness checks}

\footnotetext{
${ }^{3}$ Unfortunately, the data do not allow for distinguishing between cohabitation and marriage.

4 To interpret differences across the groups identified by the interaction between parental educational level and socio-historical context and to compare estimates from different models and samples, we followed the recommendation by Breen and colleagues (2018) and obtain effects expressed on the probability scale (see also Ai and Norton, 2003). We refrain from discussing the interactions as they appear in Table A2 in the Appendix and rather focus on the predicted probabilities for probability of contraception at first intercourse over socio-historical contexts and for type of contraception over socio-historical contexts by parental background as displayed in Figure 3 and 4 .
} 
We conducted several robustness checks for alternative model specifications. All results are available upon request. We estimated models with additional controls: the religiosity of the father and the mother when the interviewees were 14 (father's/mother's attendance at mass when the interviewee was 14: never, 1-2 times/year, $3+$ times/year, at least 1/month, at least 1/week) and own attendance at mass when the interviewee was in the first partnership of any kind (never, 12 times/year, $3+$ times/year, at least 1/month, at least 1/week). The results did not change and the coefficients for neither variable were ever significant. In the first case, the largest part of this effect is likely to be captured by parental education; in the second case, the indicator is ambiguous: in some cases, the variable may refer to the time when first intercourse occurred and in others it may not. We further adjusted the models by respondents' own highest attained educational level (at most lower secondary 59.31\%, at least upper secondary $40.69 \%$ ); because the data does not enable us to identify when each certificate/degree was attained, the attainment of the highest educational level might have occurred after first intercourse, so the effect of this variable might be endogenous. However, we regard this test as an important one as the main independent variable (parental education) may be directly associated with contraceptive behavior or indirectly via own education. The results for the variables of interest remain unchanged.

Because of the differential association between father and mother's educational level with many outcomes (e.g., egalitarian role models (Idema and Phalet, 2007) (Idema and Phalet, 2008) and educational achievements (Daouli et al., 2010; Schultz, 2002)) we estimated the models by including: only mother's education for all respondents, only father's education for all respondents, father and mother's education, and father's education for sons, and mother's education for daughters. In none of the cases did the main results change, and we decided to use highest parental education in accordance with the dominance criterion. 
We operationalize social background with parental education, which - as discussed above captures only one aspect of what social background entails. Unfortunately, our data do not include variables that allow for an alternative specification of social background (such as ISEI or a prestige indicator). The only variable that could be considered an alternative indicator for social background is maternal employment when the respondent was 14 years old; this is especially relevant in the context of Italy, where female labor market participation is highly stratified by education (higher levels of women's education correlate with higher rates of employment) and maternal employment is a predictor of daughters' future employment-related behavior and social mobility (Di Pietro and Urwin, 2003). Results of these tests were highly consistent with those presented here.

Ideally, we would have conducted a proper robustness check for the role of relative parental education on the outcome of interest, therefore accounting for parents' education relative to those born in the same year. However, the only external data available merely allow for considering the share of individuals obtaining an upper secondary certificate by academic year over the total number of individuals age 19 in that year (Italian National Statistical Institute, ISTAT historical series). Because our data do not include information on the birth year of the parents or on their age when the interviewee was born, we were unable to anchor the parents of each individual to their own birth year. As the sole alternative (and certainly suboptimal) strategy, we linked the information from the historical series to the year of birth of the respondent, by assuming that the probability of having obtained an upper secondary certificate for the parent of a given respondent when the respondent was born was the same as the probability for a 19 years-old individual. When we include this variable in our model the most important result holds (see below); in the liberal period, individuals with parents with at least upper secondary education are significantly more likely to use contraception (condom) at first intercourse compared to individuals with 
parents with at most lower secondary education. The differences by parental education are not significant for the restrictive and transformative periods.

Table 2. Distribution of the independent and control variables in the analytical sample

\begin{tabular}{lc}
\hline Variable & \% - mean \\
\hline Contraception at first intercourse & \\
No & 61.87 \\
Yes & 38.13 \\
Contraceptive method at first intercourse & \\
None & 61.87 \\
Condom & 33.52 \\
Hormonal contraceptive (pill, IUD) & 4.61 \\
Parental education & \\
at most lower sec. & 74.14 \\
at least upper sec. & 25.23 \\
missing & 0.63 \\
Gender & \\
Men & 50.97 \\
Women & 49.03 \\
Type of relationship with sexual partner & \\
Not in a relationship & 24.47 \\
In a relationship & 60.78 \\
Cohabitation/marriage & 13.88 \\
missing & 0.87 \\
Age at first intercourse & \\
Min.10-Max.24, S.D.=2.61 & 16.9 \\
Geographical area & \\
North-West & 26.77 \\
North-East & 20.06 \\
Center & 19.75 \\
South and Islands & 33.43 \\
Recio-historical context when intercourse occurred & \\
Transformative (1967-1981) & 19.18 \\
Liberal (after 1982) & 33.97 \\
in the region (after 1978) & 46.85 \\
Min.0.1-Max.5.6m, S.D.=0.87 & \\
\hline N. & \\
\hline . valid cases & 1.59 \\
\hline & 2,517 \\
\hline & 2,483 \\
\hline & \\
\hline &
\end{tabular}

Source: ISI 2006, authors' calculations. 


\section{Results}

\subsection{Descriptive results}

Figure 1 displays the descriptive trends in contraceptive use at first intercourse by parental education between the 1950 s and the 2000 s. The increase in contraception from virtually zero in the 1950 s to around $75 \%$ at the end of the observational period concerns young people from both advantaged and disadvantaged backgrounds. This descriptive picture of young Italians' experience over time seems to suggest a generalized trend towards increasing detraditionalization of intimacy with respect to contraceptive behavior at first intercourse. In the next section we explore this relationship in a multivariate setting to test our hypotheses.

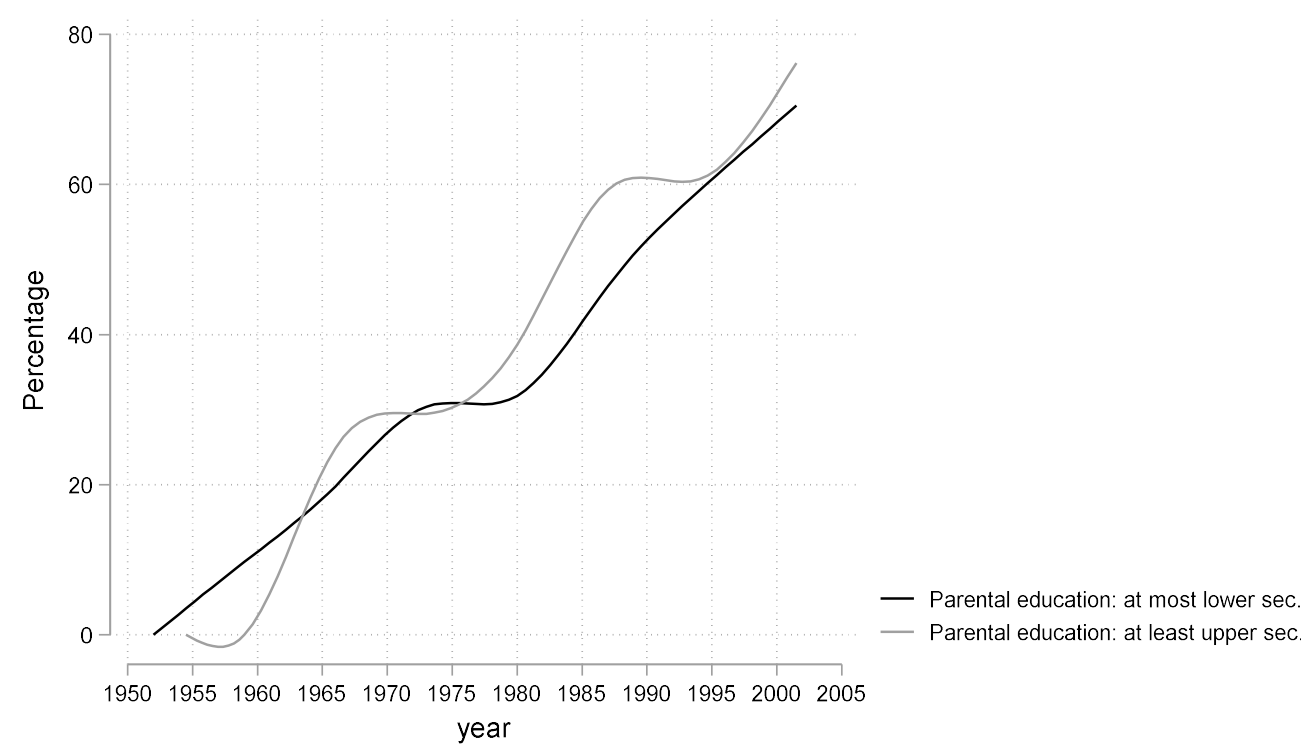

Figure 1. Young adults using contraception at first intercourse by parental education, 1960-2006 Source: ISI 2006, authors' calculations. Extrapolations based on splines.

From the literature considered above, we expect first sexual intercourse to occur increasingly outside marriage, also in the case of our analytical sample. Although our interest is specifically 
the link between social background and contraception at first intercourse over time, we acknowledge that the "locus" of first sexual intercourse is important to consider: Table 1 above shows that only around $14 \%$ of respondents in our sample were married when having sex for the first time. As the variable does not allow for distinguishing between marriage and cohabitation, the figures and the tables label this category as "cohabiting/married", but in the 2000s cohabiting couples made up less than 5 percent of all couples in Italy (ISTAT, 2010). Figure 2 displays trends in contraceptive use by type of relationship between the 1950s and the 2000s. By the mid1980s, around 40 percent of those who had first intercourse outside marriage used a contraceptive method, while this was the case for only around 18 percent of those who had sex within marriage. It is only in the mid-1990s that the use of contraception at first intercourse even among married couples approached the levels for those who had sex for the first time outside marriage (50 and 70 percent respectively), though with a persistently large gap.

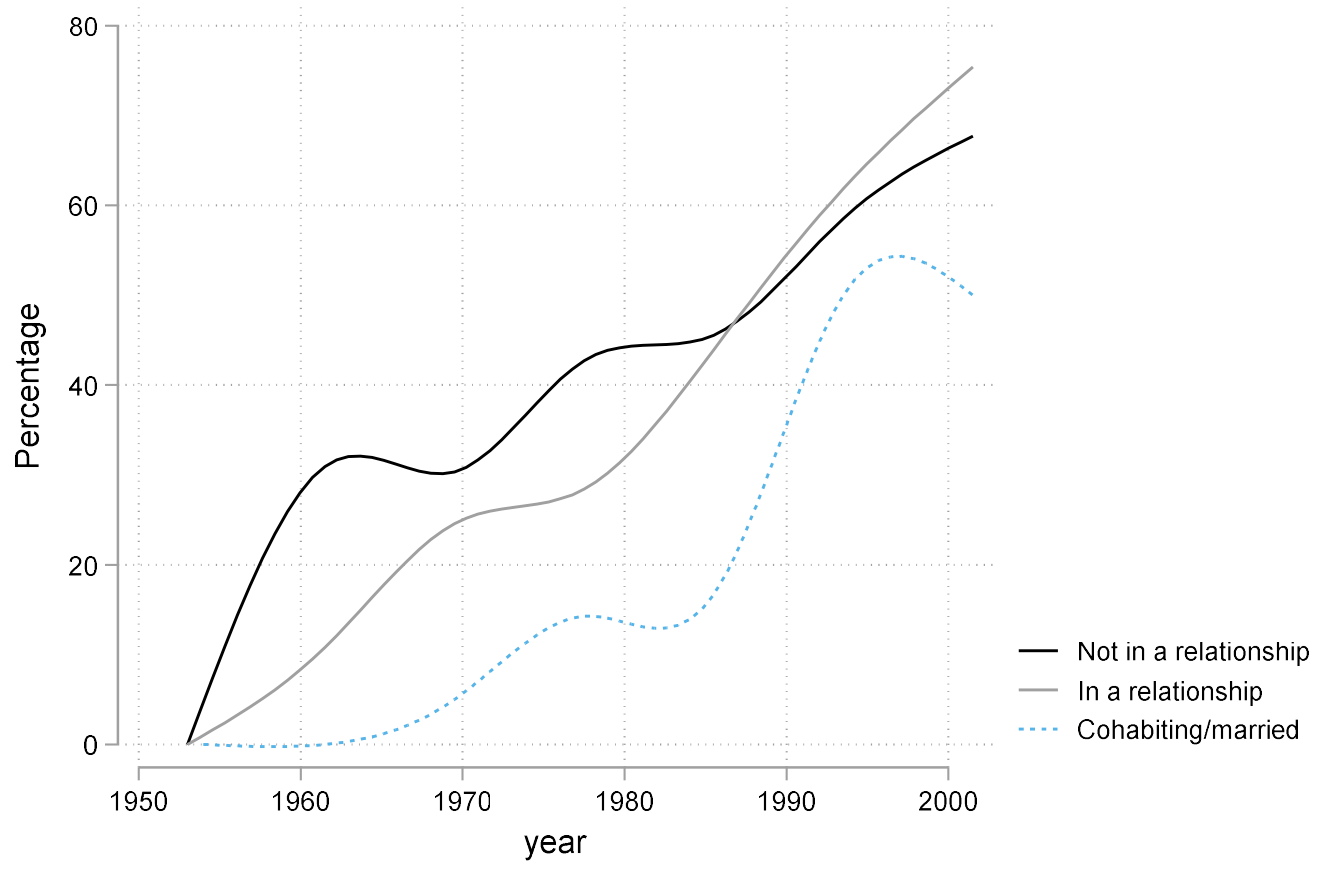


Figure 2. Young adults using contraception at first intercourse by type of relationship, 1960-2006 Source: ISI 2006, authors' calculations. Extrapolations based on splines.

\subsection{Multivariate analyses}

To address our research question on the stratified patterns of detraditionalization, we first consider the probability of any contraceptive use at first intercourse. Panel (a) in Figure 3 shows the predicted probability of contraceptive use across the three socio-historical contexts; there is a small increase from the restrictive to the transformative period (from 15 to 25 percent) followed by a steeper one from the transformative to the liberal period. For those experiencing first sexual intercourse in this socio-historical context, the probability of using any contraceptive method is around 50 percent: this confirms the massive changes in intimate sexual behavior in the direction of detraditionalization across this period in Italy, but at the same time suggests that a nonnegligible share of young people adopted traditional contraceptive methods such as coitus interruptus or used no contraception. We consider whether this trend is stratified by social background by estimating changes across the three socio-historical contexts by parental education. Panel (b) in Figure 3 shows that already in the transformative context, more advantaged young people were more likely to use any contraception at first sexual intercourse than disadvantaged young people. Although the probability of contraceptive use increased in both groups (from 14 to 25 percent and from 14 to 35 percent), for those whose parents had at least upper secondary education the change in behavior was much more pronounced $(+21 \mathrm{vs}$. +11 percentage points).

We now consider how this trend developed in the liberal phase; the non-significant difference in contraceptive use in the transformative context widens and the gap between the two groups 
becomes significant amounting to 12 percentage points $(+2$ percentage points compared to the gap in the transformative period). Young people with more educated parents had a 60 percent probability of using any contraception at first intercourse, while for those with less educated parents the probability decreased to 48 percent.

Estimates in panels (a) and (b) are from models that include fixed-effects for both the number of centers for family planning and health per 10,000 women in the region, and the geographical macro-area of residence. These do not, however, contribute to closing the gap in contraceptive behavior at first intercourse between the more advantaged and disadvantaged young people (as visible when comparing model M3 and M4 in Appendix A). That means that neither the availability of information and contraceptives offered in centers for family planning and health, nor the broader structural conditions in the macro areas explain differences in contraceptive use at first intercourse between young people from different social backgrounds in Italy. The gap is thus similar in regions with more family planning centers and those with fewer. This suggests that the institutional support structure that was installed in Italy throughout the period did little to reduce the stratification in contraceptive use when having sex for the first time, nor did it contribute more generally in pathways of detraditionalization of intimacy.

All the considerations discussed above when presenting the findings support the competing Hypothesis $1 \mathrm{~b}$, as differences by social background have widened over time. 

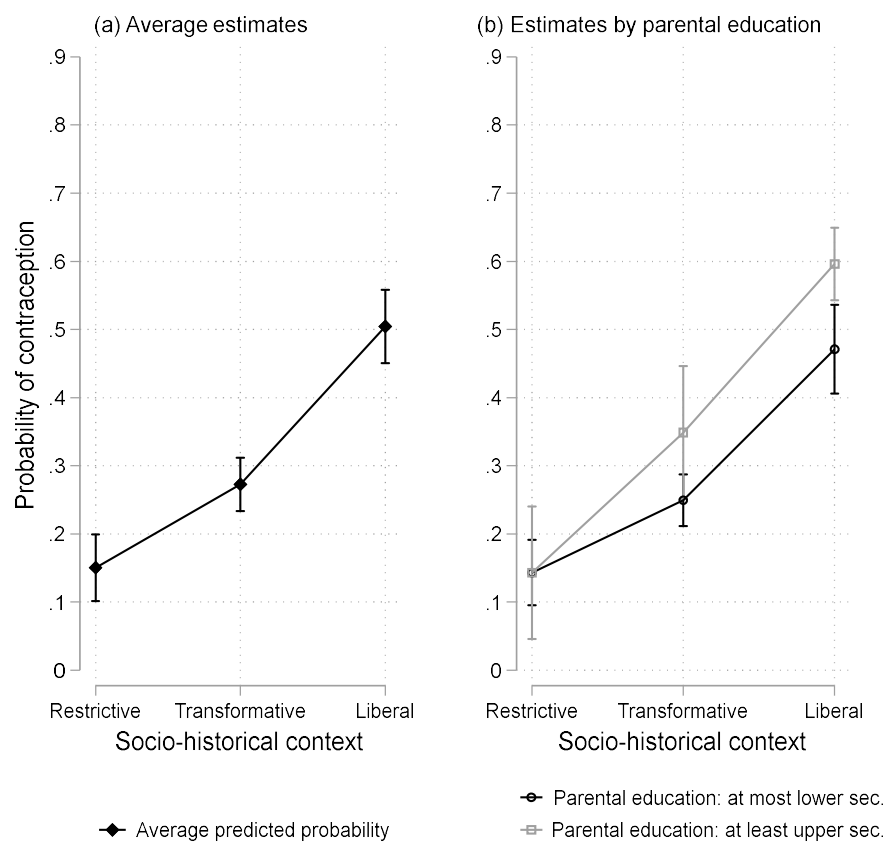

Figure 3. Logistic regression model for the probability of contraceptive use at first intercourse over time: predicted probabilities for contraceptive use

Source: ISI 2006, authors' calculations. 95\% confidence intervals. Models include fixed effects for geographical macro-area and family planning centers. Full results displayed in Table A2 in Appendix A: estimates in panel (a) from model M2, estimates in panel (b) from model M4. Weighted results.

We explore these associations further to understand whether these changes over time and difference by social background, were driven by a particular type of contraceptive method young people use. Figure 4 shows the predicted probabilities for using no contraception, condoms or hormonal contraceptive by parental education across the three socio-historical contexts. Panel (a) and (b) mirror one another: a decrease in no contraception over time corresponds to an increase in the use of condoms at first sexual intercourse. These results are consistent with evidence that shows that individuals from a more advantaged social background adopted condom use in the 1980s partly because they were also more receptive to public health campaigns 
promoting this contraceptive method against HIV and sexually transmitted diseases in general (Bajos et al., 2004).

Importantly, the differences by parental education in using this method mimic the overall trends displayed in Figure 3: the groups already start to diverge in the transformative period, and this divergence consolidates as differences grow larger in the liberal phase. In contrast, the use of hormonal methods as in panel (c) marginally increased in the transformative period for both groups. The probability of using this method remained constant (around 5 percent probability) into the liberal socio-historical context; that is until 2006. 
(a) No contraception

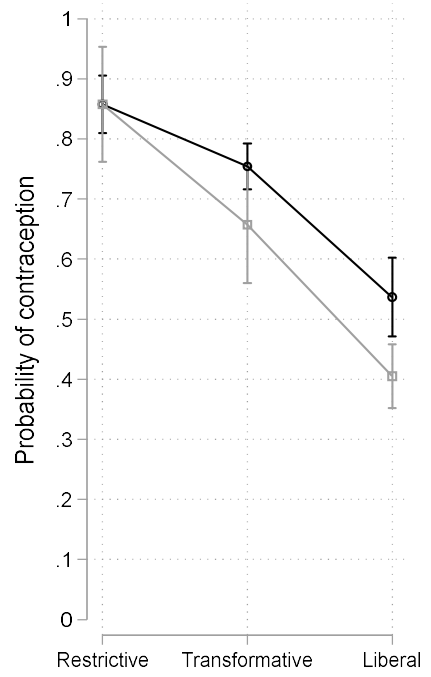

(b) Condom

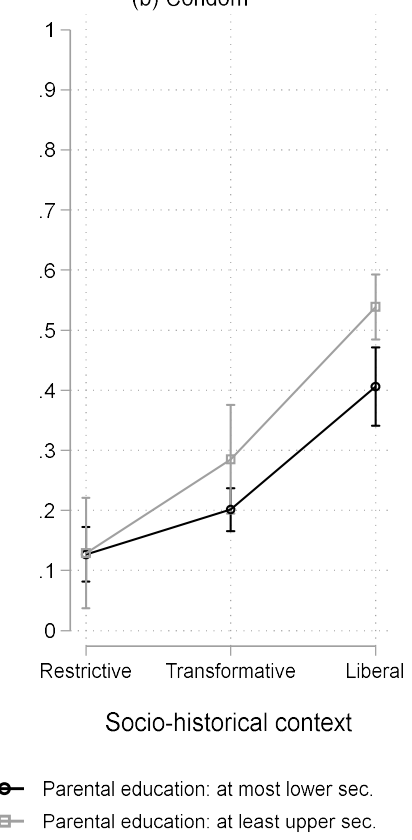

(c) Hormonal contraceptive

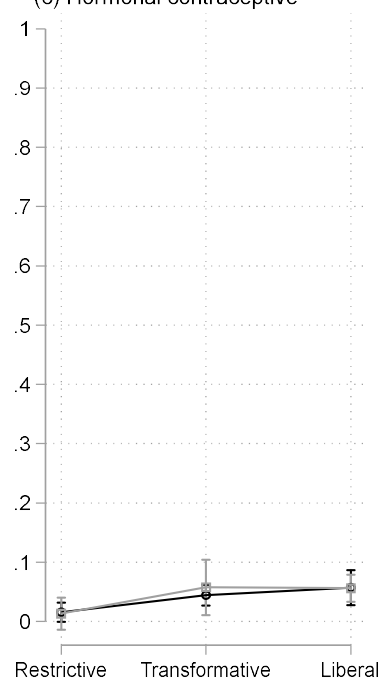

Figure 4. Logistic regression model for the probability of contraceptive use at first intercourse over time: predicted probabilities by social background and contraceptive behavior

Source: ISI 2006, authors' calculations. 95\% confidence intervals. Models include fixed effects for geographical macro-area and family planning centers. Full results displayed in Table A3 in Appendix A: estimates from model M4. Weighted results.

\section{Conclusions}

Norms and behavior around romantic sexual intimacy across the life course have detraditionalized since the middle of the last century in many countries including Italy. We distinguish three periods of detraditionalization: the restrictive period (up until the end of the 1960s), the transformative period (from the late 1960s until the early 1980s), and the liberal period (from the 1980s onwards). The trend included a decoupling of sexual initiation and marriage, an extension of the sexually active period, and massive increases in the use of modern contraceptive methods at first intercourse and beyond (Giddens, 1992). However, previous literature has suggested that there are limits to the detraditionalization of intimacy, because norms 
and behaviors are differentially adapted in different contexts and for different social groups (e.g. Treas, 2002).

For contraceptive behavior, previous research indicates socioeconomic stratification, such as class differences in contraceptive use (Eeckhaut and Sweeney, 2016; Layte et al., 2007). Socioeconomic differences in contraceptive use have been explained by factors determining young people's ability to adhere to nontraditional norms of sexual intimate behavior (Guzzo and Hayford, 2020). In light of this literature, we derive hypotheses to investigate the link between social background and the detraditionalization of intimacy by looking at changes in contraceptive use at first intercourse in Italy over the three periods of sexual liberalization.

Our analyses confirm a steep increase in the use of modern contraceptive methods at first intercourse over time in Italy between 1950 and 2006, pointing to the weakening of traditional norms around romantic sexual intimacy. However, our results also document socially stratified contraceptive behavior at first intercourse: in support of our first hypothesis, we find that young people with less educated parents did not experience the same increase in the probability of using contraception at their first intercourse as their peers with more educated parents. While young men and women with higher educated parents integrated emerging contraceptive technologies in their sexual intimate lives, this was not the case for those with the most relatively disadvantaged positions in terms of socio-economic status. We find that these patterns were particularly driven by a more pronounced increase in condom use among more advantaged young people. Our results also provide a sobering insight into the potential of institutional support to enable young people to realize reproductive autonomy, and reduce any of the inequalities in contraceptive use at first intercourse. We do not find that the diffusion of family planning centers contributed to 
fill the gap in contraceptive use between the social groups even in what we call the liberal period from the 1980s, that is, more than 25 years after their legal institutionalization.

Although young people overall in Italy show a growing individual command over sexuality, at least until 2006 there was still limited realization of personal sexual autonomy. The social divides suggest that individualization is a stratified process and that institutions - in the Italian case failed to moderate gaps between young people from different social backgrounds.

This study has some limitations that point at future research. First, our observational period ends in 2006: our data are the most recent data on a representative sample of the Italian population surveying behaviors and attitudes on sexuality that are available to researchers. The contemporary scenario of relatively widespread use of non-safe contraceptive methods across the population has seen the recent abrogation of the need for medical prescription for hormonal emergency contraception in 2016 for adults. Our findings on the persisting differences by social background in contraception at first intercourse can inform analyses of more recent trends, including the use of emergency contraception (Ceva and Moratti, 2013; Olivari et al., 2017; Turillazzi and Paolo, 2018). Future research should consider what the barriers are to the use of contraceptive methods among young people from disadvantaged social backgrounds, and in particular to using condoms. Accessibility and costs could be an issue, but also a lack of knowledge on health risks. Second, because there may be changes in the value of personal autonomy, attitudes towards sexual behavior, and the degree of conformity to social norms over the life course, a cross-sectional perspective such as ours might underestimate the role of those factors. In addition, for many respondents in our data, the interview was conducted several decades after they had had their first intercourse; this might evoke recall errors but it also limits 
the ability to draw conclusions about differences across life stages. Future initiatives should aim to provide the data infrastructure for studying these dynamics in Italy and beyond. 


\section{References}

Ai, C., Norton, E.C., 2003. Interaction terms in logit and probit models. Economics Letters, $80(1), 123-129$

Avery, L., Lazdane, G., 2008. What do we know about sexual and reproductive health of adolescents in Europe? Eur. J. Contracept. Reprod. Health Care 13, 58-70.

Bajos, N., Oustry, P., Leridon, H., Bouyer, J., Job-Spira, N., Hassoun, D., Cocon, E., 2004. Social Inequalities in Access to Contraception in France. Population Vol. 59, 415-437.

Barbagli, M., Dalla Zuanna, G., Garelli, F., 2010. La sessualità degli italiani. Il Mulino, Bologna.

Beck, U., Beck-Gernsheim, E., 2001. Individualization: Institutionalized Individualism and Its Social and Political Consequences. SAGE, London.

Beck-Gernsheim, E., 2002. Reinventing the Family: In Search of New Lifestyles. Polity Press, Malden Mass.

Bell, M.C., Edin, K., Wood, H.M., Mondé, G.C., 2018. Relationship repertoires, the price of parenthood, and the costs of contraception. Soc. Serv. Rev. 92, 313-348.

Billari, F.C., Borgoni, R., 2002. Spatial profiles in the analysis of event histories: an application to first sexual intercourse in Italy. Int. J. Popul. Geogr. 8, 261-275.

Billari, F.C., Mencarini, L., 2004. Norms and sanctions on sexual life and marriage of young adults. In: Dalla Zuanna, G., Crisafulli, C. (Eds.), Sexual Behaviour of Italian Students. Dipartimento Statistico, Università di Messina, pp. 361-379.

Billy, J.O.G., Brewster, K.L., Grady, W.R., 1994. Contextual Effects on the Sexual Behavior of Adolescent Women. J. Marriage Fam. 56, 387-404.

Birdsall, N., Chester, L.A., 1987. Contraception and the Status of Women: What is the Link? Fam. Plann. Perspect. 19, 14-18. 
Bogani, G., Cromi, A., Serati, M., Monti, Z., Apolloni, C., Nardelli, F., Naro, E.D., Ghezzi, F., 2015. Impact of School-Based Educational Programs on Sexual Behaviors Among Adolescents in Northern Italy. J. Sex Marital Ther. 41, 121-125.

Borgoni, R., Billari, F.C., 2003. Bayesian spatial analysis of demographic survey data: An application to contraceptive use at first sexual intercourse. Demogr. Res. 8, 61-92.

Bozon, M., 2003. At what age do women and men have their first sexual intercourse? World comparisons and recent trend. Popul. Soc.

Breen, R., 1997. Risk, Recommodification and Stratification. Sociology 31, 473-489.

Breen, Karloson, Hold (2018) Interpreting and Understanding Logits, Probits, and Other Nonlinear Probability Models, Annu. Rev. Sociol. 2018. 44:4.1-4.16

Brew, B., Weitzman, A., Musick, K., Kusunoki, Y., 2020. Young women's joint relationship, sex, and contraceptive trajectories: Evidence from the United States. Demogr. Res. 42, 933-984.

Buhr, P., Castiglioni, L., 2017. Family planning under financial constraints: Contraceptive use among women receiving means-tested unemployment benefits in Germany. Adv. Life Course Res. 32, 12-20.

Bukodi, E., Goldthorpe, J.H., 2013. Decomposing 'Social Origins': The Effects of Parents' Class, Status, and Education on the Educational Attainment of Their Children. Eur. Sociol. Rev. 29, 1024-1039.

Caltabiano, M., Castiglioni, M., De-Rose, A., 2020. Changes in the sexual behaviour of young people: introduction. Genus 76, 38 .

Caltabiano, M., Dalla Zuanna, G., Rosina, A., 2006. Interdependence between sexual debut and church attendance in Italy. Demogr. Res. 14, 453-484. 
Camoletto, R.F., 2011. Sexual beginners: accounting for first sexual intercourse in Italian young people's heterosexual biographies. Sex Educ. 11, 315-325.

Carpenter, L.M., 2010. Gendered Sexuality over the Life Course: A Conceptual Framework. Sociol. Perspect. 53, 155-177.

Castiglioni, M., Dalla Zuanna, G., Loghi, M., 2001. Planned and Unplanned Births and Conceptions in Italy, 1970-1995. Eur. J. Popul. 17, 207-233.

Cesareo, V., Garelli, F., Lanzetti, C., Cipriani, R., Rovati, G., 1995. La religiosità in Italia. Arnoldo Mondadori.

Coontz, S., 2000. Historical Perspectives on Family Studies. J. Marriage Fam. 62, 283-297.

Dalla Zuanna, G., Caltabiano, M., Vignoli, D., 2019. Catching up! The sexual opinions and behaviour of Italian students (2000-2017) ( No. 2019_02), Econometrics Working Papers Archive. Universita' degli Studi di Firenze, Dipartimento di Statistica, Informatica, Applicazioni “G. Parenti."

Dalla Zuanna, G., Crisafulli, C., 2004. Sexual behaviour of Italian student. University of Messina, Messina.

Dalla Zuanna, G., De Rose, A., Racioppi, F., 2005. Low fertility and limited diffusion of modern contraception in Italy during the second half of the twentieth century. J. Popul. Res. 22, 21.

Dalla Zuanna, G., Micheli, G.A., 2006. Strong family and low fertility:a paradox?: New perspectives in interpreting contemporary family and reproductive behaviour. Springer Science \& Business Media.

Daouli, J., Demoussis, M., Giannakopoulos, N., 2010. Mothers, fathers and daughters: Intergenerational transmission of education in Greece. Econ. Educ. Rev. 29, 83-93. 
Di Pietro, G., Urwin, P., 2003. Intergenerational mobility and occupational status in Italy. Appl. Econ. Lett. 10, 793-797.

Donati, S., Andreozzi, S., Medda, E., Grandolf, M.E., 2000. Salute riproduttiva tra gli adolescenti: conoscenze, attitudini e comportamenti. ( No. 00/7), RAPPORTI ISTISAN. Istituto Superiore di Sanità, Rome.

Edin, K., Kefalas, M., 2005. Promises I Can Keep: Why Poor Women Put Motherhood Before Marriage. University of California Press, Berkeley.

Eeckhaut, M.C.W., Sweeney, M.M., 2016. The perplexing links between contraceptive sterilization and (dis)advantage in ten low-fertility countries. Popul. Stud. 70, 39-58.

England, P., 2016. Sometimes the Social Becomes Personal: Gender, Class, and Sexualities. Am. Sociol. Rev. 81, 4-28.

Farre, L., Vella, F., 2013. The Intergenerational Transmission of Gender Role Attitudes and its Implications for Female Labour Force Participation. Economica 80, 219-247.

Ferrero Camoletto, R.F., 2014. Fare sesso, fare genere? Un'analisi dei copioni sessuali dei giovani uomini al primo rapporto sessuale. Rassegna Ital. Sociol.

Garelli, F., Guizzardi, G., Pace, E. (Eds.), 2003. Un singolare pluralismo. Il Mulino, Bologna.

Giddens, A., 1991. Modernity and Self-identity: Self and Society in the Late Modern Age. Stanford University Press.

Giddens, A., 1992. The Transformation of Intimacy: Sexuality, Love and Eroticism in Modern Societies. Stanford University Press, Stanford, California.

Goldscheider, F., Bernhardt, E., Lappegård, T., 2015. The Gender Revolution: A Framework for Understanding Changing Family and Demographic Behavior. Popul. Dev. Rev. 41, 207239.

Goldthorpe, J.H., 2002. Globalisation and Social Class. West Eur. Polit. 25, 1-28. 
Gross, N., 2005. The Detraditionalization of Intimacy Reconsidered. Sociol. Theory 23, 286311.

Guzzo, K., Hayford, S.R., 2020. Pathways to Parenthood in Social and Family Contexts: Decade in Review, 2020.

I Consultori Familiari a 40 anni dalla loro nascita tra passato, presente e futuro, 2018. , Rapporto di Convegno. Istituto Superiore di Sanità, Rome.

Idema, H., Phalet, K., 2007. Transmission of gender-role values in Turkish-German migrant families: The role of gender, intergenerational and intercultural relations. ZfF $-\mathrm{Z}$. Für Fam. J. Fam. Res. 19.

IPPFN, 2015. Women's access to modern contraceptive choice - Barometer 2015. International Planned Parenthood Federation European Network, Brussels.

ISTAT, 2010. La vita quotidiana nel 2009. Indagine multiscopo sulle famiglie 'Aspetti della vita quotidiana.' Istituto Nazionale di Statistica, Rome.

ISTAT, 2017. La salute riproduttiva della donna. Istituto Nazionale di Statistica, Rome.

Johnson, S., Pion, C., Jennings, V., 2013. Current methods and attitudes of women towards contraception in Europe and America. Reprod. Health 10, 7.

Layte, R., McGee, H., Rundle, K., Leigh, C., 2007. Does ambivalence about becoming pregnant explain social class differentials in use of contraception? Eur. J. Public Health 17, 477482.

Léridon, H., 1987. La Seconde révolution contraceptive: la régulation des naissances en France de 1950 à 1985. INED.

Lesthaeghe, R., 1995. The Second Demographic Transition in western Countries: An Interpretation. In: Mason, K.O., Jensen, A.-M. (Eds.), Gender and Family Change in Industrialized Countries. Clarendon Press, pp. 17-62. 
Lesthaeghe, R., 1998. On Theory Development: Applications to the Study of Family Formation. Popul. Dev. Rev. 24, 1-14.

Lindberg, L.D., Maddow-Zimet, I., 2012. Consequences of Sex Education on Teen and Young Adult Sexual Behaviors and Outcomes. J. Adolesc. Health 51, 332-338.

Long, J.S., Freese, J., 2014. Regression Models for Categorical Dependent Variables Using Stata. StataCorp LP, College Station, Tex.

Manning, W.D., Longmore, M.A., Giordano, P.C., 2000. The Relationship Context of Contraceptive Use at First Intercourse. Fam. Plann. Perspect. 32, 104-110.

Mauldon, J., Luker, K., 1996. The Effects of Contraceptive Education on Method Use at First Intercourse. Fam. Plann. Perspect. 28, 19-41.

Ministero della Sanità, 1992. Linee guida per gli interventi di educazione alla salute e di prevenzione delle infezioni da HIV nella scuola ( No. 92/4), RAPPORTI ISTISAN. Istituto Superiore di Sanità, Rome.

Moen, P., Erickson, M.A., Dempster-McClain, D., 1997. Their Mother's Daughters? The Intergenerational Transmission of Gender Attitudes in a World of Changing Roles. J. Marriage Fam. 59, 281-293.

Musick, K., England, P., Edgington, S., Kangas, N., 2009. Education Differences in Intended and Unintended Fertility. Soc. Forces 88, 543-572.

OECD, 2017. The Pursuit of Gender Equality: An Uphill Battle. OECD Publishing, Paris.

Pekkurnaz, D., 2019. Employment Status and Contraceptive Choices of Women With Young Children in Turkey. Fem. Econ. 0, 1-23.

Pirani, E., Vignoli, D., 2016. Changes in the Satisfaction of Cohabitors Relative to Spouses over Time. J. Marriage Fam. 78, 598.

Platt, L., 2019. Understanding Inequalities: Stratification and Difference. John Wiley \& Sons. 
Reed, J., England, P., Littlejohn, K., Bass, B.C., Caudillo, M.L., 2014. Consistent and Inconsistent Contraception Among Young Women: Insights from Qualitative Interviews. Fam. Relat. 63, 244-258.

Rifelli, G., Ziglio, C., 1991. Per una storia dell'educazione sessuale. La Nuova Italia, Firenze.

Rosina, A., Fraboni, R., 2004. Is marriage losing its centrality in Italy? Demogr. Res. 11, 149172.

Sagebin Bordini, G., Sperb, T.M., 2013. Sexual Double Standard: A Review of the Literature Between 2001 and 2010. Sex. Cult. 17, 686-704.

Sawyer, S.M., Azzopardi, P.S., Wickremarathne, D., Patton, G.C., 2018. The age of adolescence. Lancet Child Adolesc. Health 2, 223-228.

Schultz, P.T., 2002. Why Governments Should Invest More to Educate Girls. World Dev. 30, $207-225$.

Sironi, M., Barban, N., Impicciatore, R., 2015. Parental social class and the transition to adulthood in Italy and the United States. Adv. Life Course Res. 26, 89-104.

Spinelli, A., Figá Talamanca, A., Lauria, L., European Study Group on Infertility, and Subfecundity, 2000. Patterns of contraceptive use in 5 European countries. Am. J. Public Health 90, 1403-1408.

Spinelli, A., Grandolfo, M., Donati, S., Medda, E., 1993. Family planning in Italy. Adv. Contracept. 9, 153-160.

Sprecher, S., Harris, G., Meyers, A., 2008. Perceptions of Sources of Sex Education and Targets of Sex Communication: Sociodemographic and Cohort Effects. J. Sex Res. 45, 17-26.

SVIMEZ, 2019. Rapporto sull'economia e la società del Mezzogiorno. Associazione per lo sviluppo dell'industria nel Mezzogiorno.

Therborn, G., 2004. Between Sex and Power: Family in the World 1900-2000. Routledge. 
Treas, J., 2002. How Cohorts, Education, and Ideology Shaped a New Sexual Revolution on American Attitudes toward Nonmarital Sex, 1972-1998. Sociol. Perspect. 45, 267-283.

Vignoli, D., Salvini, S., 2014. Religion and union formation in Italy: Catholic precepts, social pressure, and tradition. Demogr. Res. 31, 1079-1106.

Volante, R., Genta, F., Scansetti, G., Seinera, P., Svanosio, M., Sismondi, P., 1978. Prime mille consultazioni di contraccezione in un centro di pianificazione familiare (AIEMP) di Torino (note 1 e 2). Contraccez. Fertil. Sessual. 5, 297-305. 


\section{Appendix A}

Figure A1. Centers for family planning and health per 10,000 women between 15 and 49 yearold across regions and over time (with impute missing information)

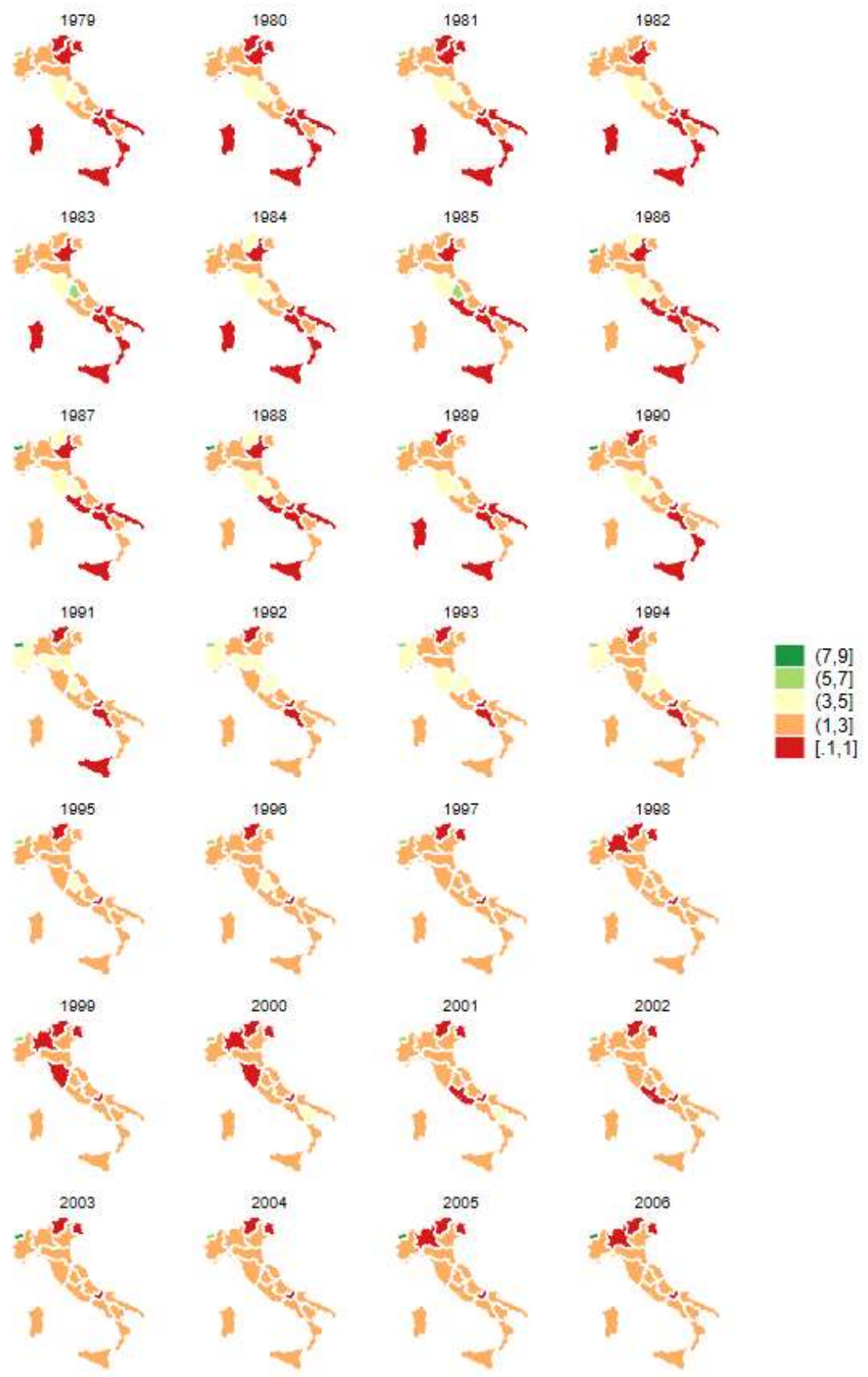

Source: Report of the Ministry on the implementation of the Law 194/1978 for the social protection of motherhood and legal abortion (1979-2006) and ISTAT. 
Table A1: Centers for family planning and health per 10,000 women between 15 and 49 year-old across regions and over time (with missing information)

\begin{tabular}{|c|c|c|c|c|c|c|c|c|c|c|c|c|c|c|c|c|c|c|c|c|c|c|c|c|c|c|c|c|c|c|}
\hline Region & 1978 & 1979 & 1980 & 1981 & 1982 & 1983 & 1984 & 1985 & 1986 & 1987 & 1988 & 1989 & 1990 & 1991 & 1992 & 1992 & 1993 & 1994 & 1995 & 1996 & 1997 & 1998 & 1999 & 2000 & 2001 & 2002 & 2003 & 2004 & 2005 & 2006 \\
\hline Piemonte & 1.1 & & & 1.6 & 1.7 & 1.7 & 1.7 & 1.7 & 1.7 & 1.7 & & 2.1 & 1.9 & 3.3 & 3.3 & 3.3 & & 2.3 & 2 & & 2.0 & 2.7 & 2.1 & 1.8 & & 2 & 2.2 & 2.3 & 1.9 & 2.2 \\
\hline Valle d'Aosta & & & & 6.7 & 6.7 & 7.0 & 7.0 & 7.0 & 7.8 & 7.8 & & 6.3 & 8.7 & 8.7 & 6.3 & 6.2 & 6.2 & 6.2 & 6.2 & & 6.2 & 6.2 & 6.3 & 5.6 & 6.3 & 6.4 & 7.1 & 6 & 7.1 & 7.7 \\
\hline Lombardia & & & & 1.4 & 1.5 & 1.4 & 1.3 & 1.4 & 2.5 & 1.5 & & 1.5 & 1.5 & 1.5 & 1.5 & 1.5 & 1.5 & 1.4 & 1.3 & & 1.3 & 1.0 & 0.8 & 0.8 & 1.3 & 1.2 & 1.1 & 1.1 & 1 & 1 \\
\hline Trentino Alto-Adige & & & & 1.0 & 2.2 & 2.1 & 4.3 & 2.1 & 4.1 & 4.1 & & 0.4 & 0.5 & 0.4 & 0.4 & 0.5 & 0.5 & 0.4 & 0.1 & & 0.1 & 0.1 & 0.4 & 0.4 & 0.4 & 0.4 & 0.4 & 0.4 & 0.7 & 0.9 \\
\hline Veneto & & & & 0.8 & 0.9 & 0.9 & 1.0 & 1.0 & 0.9 & 0.9 & & 1.1 & 1.4 & 1.4 & 1.4 & 1.3 & 1.3 & 1.3 & 1.3 & & 1.3 & 1.3 & 1.3 & 1.3 & 1.3 & 1.4 & 1.3 & 1.4 & 1.3 & 1.2 \\
\hline Friuli Venezia Giulia & & & & 0.8 & 1.9 & 1.9 & 1.2 & 1.9 & 1.1 & 1.1 & & 1.1 & 1.9 & 2 & 1.9 & 2 & 2 & 2 & 0.8 & & 0.8 & 0.8 & 0.8 & 0.8 & 0.8 & 0.8 & 0.8 & 0.8 & 0.8 & 0.8 \\
\hline Liguria & 0.5 & & & 2.8 & 2.8 & 2.3 & 2.3 & 2.3 & 2.3 & 2.3 & & 2.9 & 2.9 & 2.9 & 2.9 & 3 & 3 & 3 & 2.6 & & 2.6 & 2.6 & 2.6 & 2.6 & & & & & 2.6 & 2.6 \\
\hline Emilia Romagna & & & & 1.8 & 1.8 & 2.9 & 2.9 & 2.9 & 3.0 & 3 & & 2.9 & 3 & 3.1 & & 3 & 2.7 & 2.8 & 2.6 & & 2.6 & 2.6 & 2.6 & 2.6 & 2.5 & 2.5 & 2.4 & 2.3 & 2.3 & 2.3 \\
\hline Toscana & & & & 3.9 & 4.0 & 4.0 & 4.0 & 3.9 & 3.9 & 3.9 & & 3.5 & 3.5 & 2.4 & 2.5 & 3.6 & 2.6 & 1.9 & 1.1 & & 1.1 & 2.0 & 0.9 & & 2.9 & 2.9 & 2.9 & 2.8 & 2.5 & 2.5 \\
\hline Umbria & & & & 3.5 & 3.8 & 5.1 & 3.4 & 5.6 & 3.9 & 3.9 & & 3.8 & 3.9 & 3.9 & 3.9 & 4 & 4 & 3.8 & 2.4 & & 2.4 & 2.2 & & 1.8 & 1.8 & 2 & 1.8 & 1.8 & 1.8 & 1.7 \\
\hline Marche & & & & 1.6 & 2.7 & 2.7 & 2.6 & 2.9 & 2.8 & 2.8 & & 2.8 & 2.8 & 2.8 & 3.1 & 3.1 & 3.1 & 1.9 & 2.2 & & 2.2 & 2.2 & 1.1 & 1.2 & & 1.1 & & 1.1 & 1.1 & 2.1 \\
\hline Lazio & & & & 1.1 & 1.1 & 1.1 & 1.1 & 0.9 & 0.9 & 1 & & 1.8 & 1.5 & 1.4 & 1.4 & 1.3 & 1.3 & 1.2 & 1.3 & & 1.3 & 1.3 & 1.3 & 1.3 & 1 & & 1.2 & 1.2 & 1.2 & 1.3 \\
\hline Abruzzo & & & & 2.0 & 2.0 & 2.2 & 2.1 & 2.1 & 2.0 & 2 & & 2.1 & 2.1 & 2.3 & 2.5 & 2.5 & & 2.7 & 2.4 & & 2.4 & 2.3 & 2.7 & 2.7 & 2.4 & 2.5 & 2.4 & 2.5 & 2.4 & 2.4 \\
\hline Molise & & & & 0.3 & 0.7 & 0.9 & 0.9 & 0.8 & 0.9 & 0.9 & & 0.9 & 0.9 & 0.9 & 0.8 & 0.9 & 0.9 & 0.9 & 0.9 & & 0.9 & 0.9 & 0.9 & 0.9 & 0.9 & 0.9 & & & 0.9 & 0.9 \\
\hline Campania & & & & 0.5 & 0.7 & 0.8 & 0.8 & 0.8 & 0.7 & 0.7 & & 0.8 & 0.8 & 0.8 & 0.8 & 1 & 1 & 1.2 & 1.2 & & 1.2 & 1.2 & & 1.1 & 1.2 & & 1.1 & 1.1 & 1.1 & 1.2 \\
\hline Puglia & & & & 1.0 & 1.0 & 1.0 & 0.9 & 0.9 & 0.9 & 0.9 & & 1 & 1.1 & 1.3 & 1.4 & 1.4 & 1.4 & 1.4 & 1.3 & & 1.3 & 1.4 & 1.4 & 1.4 & & & 1.5 & 1.6 & 1.6 & 1.6 \\
\hline basilicata & & & & 2.1 & 2.4 & 1.6 & 2.4 & 2.5 & 2.5 & 2.5 & & 2.4 & 2.3 & 2.3 & 2.3 & 2.3 & 2.3 & 2.3 & 2.3 & & 2.3 & 2.3 & 2.3 & 3.2 & & 2.4 & 1.9 & 2.4 & 2.4 & 2.4 \\
\hline Calabria & & & & 0.6 & 0.6 & 0.8 & 0.8 & 1.1 & 1.1 & 1.1 & & 1.1 & 0.9 & 1.1 & 1.1 & 1.3 & 1.4 & 1.4 & 1.4 & & 1.4 & 1.4 & 1.4 & 1.3 & & 1.4 & 1.4 & & 1.4 & 1.5 \\
\hline Sicilia & & & & 0.1 & 0.4 & 0.4 & 0.5 & 0.5 & 0.4 & 0.4 & & 0.8 & 1 & 1 & 1.2 & 1.4 & 1.4 & 1.4 & 1.4 & & 1.4 & 1.4 & 1.4 & 1.4 & & 1.4 & & 1.4 & 1.1 & 1.4 \\
\hline Sardegna & & & & 0.3 & 0.3 & 1.0 & 1.0 & 1.4 & 1.3 & 1.3 & & 1 & 1.4 & 1.4 & 1.5 & 1.6 & 2 & 1.6 & 1.8 & & 1.8 & 1.8 & 1.8 & 1.8 & & 1.8 & 1.8 & 1.5 & 1.9 & 1.9 \\
\hline
\end{tabular}

Source: Report of the Ministry on the implementation of the Law 194/1978 for the social protection of motherhood and legal abortion (1979-2006) and

ISTAT. 
Table A2: Logistic regression model for the probability of contraceptive use at first intercourse over socio-historical contexts, odds ratios

\begin{tabular}{|c|c|c|c|c|}
\hline & M1 & M2 & M3 & M4 \\
\hline \multicolumn{5}{|l|}{$\begin{array}{l}\text { Socio-historical context when first intercourse occurred (ref. } \\
\text { Restrictive [before 1967]) }\end{array}$} \\
\hline Transformative (1967-1981) & $\begin{array}{c}2.14 * * * * \\
(0.39)\end{array}$ & $\begin{array}{c}2.13^{* * *} \\
(0.41)\end{array}$ & $\begin{array}{c}2.00^{* * * *} \\
(0.40)\end{array}$ & $\begin{array}{c}1.99 * * * \\
(0.41)\end{array}$ \\
\hline Liberal (after 1982) & $\begin{array}{c}6.31^{* * *} \\
(1.11)\end{array}$ & $\begin{array}{c}5.79 * * * \\
(1.49)\end{array}$ & $\begin{array}{c}5.77^{* * *} \\
(1.14)\end{array}$ & $\begin{array}{c}5.34 * * * \\
(1.45)\end{array}$ \\
\hline \multicolumn{5}{|l|}{ Parental education (ref: At most lower sec.) } \\
\hline At least upper sec. & $\begin{array}{c}0.62^{* * *} \\
(0.07)\end{array}$ & $\begin{array}{c}0.62^{* * *} \\
(0.07)\end{array}$ & $\begin{array}{c}0.62 * * * \\
(0.07)\end{array}$ & $\begin{array}{c}0.62 * * * \\
(0.07)\end{array}$ \\
\hline \multicolumn{5}{|l|}{ Gender (ref.: Men) } \\
\hline Women & $\begin{array}{c}0.99 \\
(0.02)\end{array}$ & $\begin{array}{c}1.00 \\
(0.02)\end{array}$ & $\begin{array}{c}0.99 \\
(0.02)\end{array}$ & $\begin{array}{c}1.00 \\
(0.02)\end{array}$ \\
\hline Age at 1 st intercourse & $\begin{array}{c}1.22 \\
(0.14)\end{array}$ & $\begin{array}{c}1.16 \\
(0.13)\end{array}$ & $\begin{array}{c}0.73 \\
(0.30)\end{array}$ & $\begin{array}{c}0.71 \\
(0.29)\end{array}$ \\
\hline \multicolumn{5}{|l|}{ Type of relationship with sexual partner (ref.: Not in a relationship) } \\
\hline In a relationship & $\begin{array}{c}1.06 \\
(0.14)\end{array}$ & $\begin{array}{c}1.06 \\
(0.14)\end{array}$ & $\begin{array}{c}1.06 \\
(0.14)\end{array}$ & $\begin{array}{c}1.07 \\
(0.14)\end{array}$ \\
\hline Cohabitation/marriage & $\begin{array}{c}0.24 * * * \\
(0.07)\end{array}$ & $\begin{array}{c}0.27^{* * *} \\
(0.08)\end{array}$ & $\begin{array}{c}0.24 * * * \\
(0.07)\end{array}$ & $\begin{array}{c}0.27 * * * \\
(0.08)\end{array}$ \\
\hline \multicolumn{5}{|l|}{ Size of the city (ref.: Up to 5000) } \\
\hline $5001-10000$ & $\begin{array}{c}0.88 \\
(0.16)\end{array}$ & $\begin{array}{c}0.88 \\
(0.16)\end{array}$ & $\begin{array}{c}0.87 \\
(0.16)\end{array}$ & $\begin{array}{c}0.87 \\
(0.16)\end{array}$ \\
\hline $10001-30000$ & $\begin{array}{c}0.91 \\
(0.14)\end{array}$ & $\begin{array}{c}0.91 \\
(0.15)\end{array}$ & $\begin{array}{c}0.91 \\
(0.14)\end{array}$ & $\begin{array}{c}0.91 \\
(0.15)\end{array}$ \\
\hline $30001-100000$ & $\begin{array}{c}0.86 \\
(0.14)\end{array}$ & $\begin{array}{c}0.94 \\
(0.15)\end{array}$ & $\begin{array}{c}0.86 \\
(0.14)\end{array}$ & $\begin{array}{c}0.93 \\
(0.15)\end{array}$ \\
\hline 100001 a 500000 & $\begin{array}{c}0.91 \\
(0.17)\end{array}$ & $\begin{array}{c}0.85 \\
(0.16)\end{array}$ & $\begin{array}{c}0.91 \\
(0.17)\end{array}$ & $\begin{array}{c}0.85 \\
(0.16)\end{array}$ \\
\hline $500000+$ & $\begin{array}{c}1.01 \\
(0.19)\end{array}$ & $\begin{array}{c}1.06 \\
(0.20)\end{array}$ & $\begin{array}{c}1.01 \\
(0.19)\end{array}$ & $\begin{array}{c}1.06 \\
(0.20)\end{array}$ \\
\hline Transformative (1967-1981) * Parental education: at least upper sec. & & & $\begin{array}{c}1.66 \\
(0.78)\end{array}$ & $\begin{array}{c}1.66 \\
(0.78)\end{array}$ \\
\hline Liberal (after 1982) * Parental education: at least upper sec. & & & $\begin{array}{c}1.76 \\
(0.77) \\
\end{array}$ & $\begin{array}{c}1.71 \\
(0.75) \\
\end{array}$ \\
\hline Family centres & & $\mathrm{x}$ & & $\mathrm{x}$ \\
\hline Geographical macro-area & & $\mathrm{x}$ & & $\mathrm{x}$ \\
\hline$N$ & 2,485 & 2,483 & 2,485 & 2,483 \\
\hline R2 & 0.14 & 0.15 & 0.14 & 0.15 \\
\hline
\end{tabular}

Source: ISI 2006, authors' calculations. Weighted results. 
Table A3: Multinomial logistic regression model for the probability of contraceptive use at first intercourse and contraceptive method, relative-risk ratios

\begin{tabular}{|c|c|c|c|c|c|c|c|c|}
\hline & \multicolumn{2}{|c|}{ M1 } & \multicolumn{2}{|c|}{ M2 } & \multicolumn{2}{|r|}{ M3 } & \multicolumn{2}{|c|}{ M4 } \\
\hline & Condoms & $\begin{array}{c}\text { Hormonal } \\
\text { contraceptive }\end{array}$ & Condoms & $\begin{array}{c}\text { Hormonal } \\
\text { contraceptive }\end{array}$ & Condoms & $\begin{array}{c}\text { Hormonal } \\
\text { contraceptive }\end{array}$ & Condoms & $\begin{array}{c}\text { Hormonal } \\
\text { contraceptive }\end{array}$ \\
\hline \multicolumn{9}{|l|}{ Socio-historical context when first intercourse occurred (ref. Restrictive [before 1967]) } \\
\hline Transformative (1967-1981) & $\begin{array}{c}1.99 * * * \\
(0.39)\end{array}$ & $\begin{array}{l}3.34^{*} \\
(1.61)\end{array}$ & $\begin{array}{c}1.97 * * * \\
(0.40)\end{array}$ & $\begin{array}{l}3.38^{*} \\
(1.70)\end{array}$ & $\begin{array}{l}1.86^{* *} \\
(0.39)\end{array}$ & $\begin{array}{l}3.10^{*} \\
(1.62)\end{array}$ & $\begin{array}{c}1.85^{* *} \\
(0.41)\end{array}$ & $\begin{array}{l}3.14^{*} \\
(1.72)\end{array}$ \\
\hline Liberal (after 1982) & $\begin{array}{c}6.25 * * * \\
(1.16)\end{array}$ & $\begin{array}{c}6.70 * * * \\
(3.09)\end{array}$ & $\begin{array}{c}5.74 * * * \\
(1.56)\end{array}$ & $\begin{array}{l}5.87 * * \\
(3.68)\end{array}$ & $\begin{array}{c}5.70 * * * \\
(1.18)\end{array}$ & $\begin{array}{l}6.23 * * * \\
(3.16)\end{array}$ & $\begin{array}{c}5.27 * * * \\
(1.51)\end{array}$ & $\begin{array}{c}5.61 * * \\
(3.70)\end{array}$ \\
\hline \multicolumn{9}{|l|}{ Parental education (ref: At most lower sec.) } \\
\hline At least upper sec. & $\begin{array}{c}1.22 \\
(0.14)\end{array}$ & $\begin{array}{c}1.20 \\
(0.29)\end{array}$ & $\begin{array}{c}1.16 \\
(0.14)\end{array}$ & $\begin{array}{c}1.11 \\
(0.27)\end{array}$ & $\begin{array}{c}0.73 \\
(0.31)\end{array}$ & $\begin{array}{c}0.70 \\
(0.79)\end{array}$ & $\begin{array}{c}0.70 \\
(0.31)\end{array}$ & $\begin{array}{c}0.71 \\
(0.79)\end{array}$ \\
\hline \multicolumn{9}{|l|}{ Gender (ref:: Men) } \\
\hline Women & $\begin{array}{c}0.60^{* * * *} \\
(0.07)\end{array}$ & $\begin{array}{c}0.76 \\
(0.17)\end{array}$ & $\begin{array}{c}0.60 * * * \\
(0.07)\end{array}$ & $\begin{array}{c}0.76 \\
(0.17)\end{array}$ & $\begin{array}{c}0.61^{* * * *} \\
(0.07)\end{array}$ & $\begin{array}{c}0.77 \\
(0.17)\end{array}$ & $\begin{array}{c}0.60 * * * \\
(0.07)\end{array}$ & $\begin{array}{c}0.76 \\
(0.17)\end{array}$ \\
\hline Age at lst intercourse & $\begin{array}{c}0.99 \\
(0.02)\end{array}$ & $\begin{array}{l}1.04 \\
(0.05)\end{array}$ & $\begin{array}{c}0.99 \\
(0.02)\end{array}$ & $\begin{array}{l}1.05 \\
(0.05)\end{array}$ & $\begin{array}{c}0.99 \\
(0.02)\end{array}$ & $\begin{array}{l}1.05 \\
(0.05)\end{array}$ & $\begin{array}{c}0.99 \\
(0.02)\end{array}$ & $\begin{array}{l}1.05 \\
(0.05)\end{array}$ \\
\hline \multicolumn{9}{|l|}{ Type of relationship with sexual partner (ref:: Not in a relationship) } \\
\hline In a relationship 1 & $\begin{array}{c}1.10 \\
(0.15)\end{array}$ & $\begin{array}{c}0.80 \\
(0.20)\end{array}$ & $\begin{array}{c}1.11 \\
(0.15)\end{array}$ & $\begin{array}{c}0.80 \\
(0.20)\end{array}$ & $\begin{array}{c}1.10 \\
(0.15)\end{array}$ & $\begin{array}{c}0.80 \\
(0.20)\end{array}$ & $\begin{array}{c}1.11 \\
(0.15)\end{array}$ & $\begin{array}{c}0.80 \\
(0.20)\end{array}$ \\
\hline Cohabitation/marriage & $\begin{array}{c}0.21^{* * * *} \\
(0.07)\end{array}$ & $\begin{array}{c}0.37 \\
(0.20)\end{array}$ & $\begin{array}{c}0.23^{* * * *} \\
(0.07)\end{array}$ & $\begin{array}{c}0.43 \\
(0.24)\end{array}$ & $\begin{array}{c}0.21^{* * * *} \\
(0.07)\end{array}$ & $\begin{array}{c}0.36 \\
(0.20)\end{array}$ & $\begin{array}{c}0.23^{* * * *} \\
(0.07)\end{array}$ & $\begin{array}{c}0.43 \\
(0.24)\end{array}$ \\
\hline \multicolumn{9}{|l|}{ Size of the city (ref.: Up to 5000) } \\
\hline $5001-10000$ & $\begin{array}{c}0.89 \\
(0.17)\end{array}$ & $\begin{array}{c}0.81 \\
(0.30)\end{array}$ & $\begin{array}{c}0.89 \\
(0.17)\end{array}$ & $\begin{array}{c}0.82 \\
(0.31)\end{array}$ & $\begin{array}{c}0.88 \\
(0.17)\end{array}$ & $\begin{array}{c}0.80 \\
(0.30)\end{array}$ & $\begin{array}{c}0.88 \\
(0.17)\end{array}$ & $\begin{array}{c}0.82 \\
(0.31)\end{array}$ \\
\hline $10001-30000$ & $\begin{array}{c}0.92 \\
(0.15)\end{array}$ & $\begin{array}{c}0.83 \\
(0.26)\end{array}$ & $\begin{array}{c}0.93 \\
(0.15)\end{array}$ & $\begin{array}{c}0.86 \\
(0.26)\end{array}$ & $\begin{array}{c}0.92 \\
(0.15)\end{array}$ & $\begin{array}{c}0.83 \\
(0.26)\end{array}$ & $\begin{array}{c}0.92 \\
(0.15)\end{array}$ & $\begin{array}{c}0.86 \\
(0.26)\end{array}$ \\
\hline 30001-100000 & $\begin{array}{c}0.91 \\
(0.15)\end{array}$ & $\begin{array}{c}0.60 \\
(0.21)\end{array}$ & $\begin{array}{c}0.99 \\
(0.17)\end{array}$ & $\begin{array}{c}0.66 \\
(0.23)\end{array}$ & $\begin{array}{c}0.91 \\
(0.15)\end{array}$ & $\begin{array}{c}0.59 \\
(0.21)\end{array}$ & $\begin{array}{c}0.98 \\
(0.17)\end{array}$ & $\begin{array}{c}0.66 \\
(0.23)\end{array}$ \\
\hline 100001 a 500000 & $\begin{array}{c}0.94 \\
(0.18)\end{array}$ & $\begin{array}{c}0.81 \\
(0.31)\end{array}$ & $\begin{array}{c}0.87 \\
(0.18)\end{array}$ & $\begin{array}{c}0.79 \\
(0.30)\end{array}$ & $\begin{array}{c}0.93 \\
(0.18)\end{array}$ & $\begin{array}{c}0.80 \\
(0.31)\end{array}$ & $\begin{array}{c}0.86 \\
(0.17)\end{array}$ & $\begin{array}{c}0.78 \\
(0.29)\end{array}$ \\
\hline $500000+$ & $\begin{array}{c}1.09 \\
(0.20)\end{array}$ & $\begin{array}{c}0.60 \\
(0.27)\end{array}$ & $\begin{array}{c}1.14 \\
(0.22)\end{array}$ & $\begin{array}{c}0.60 \\
(0.27)\end{array}$ & $\begin{array}{c}1.09 \\
(0.21)\end{array}$ & $\begin{array}{c}0.60 \\
(0.27)\end{array}$ & $\begin{array}{c}1.14 \\
(0.22)\end{array}$ & $\begin{array}{c}0.60 \\
(0.28)\end{array}$ \\
\hline Transformative (1967-1981) * Parental education: at least upper sec. & & & & & $\begin{array}{c}1.65 \\
(0.81)\end{array}$ & $\begin{array}{c}1.83 \\
(2.21)\end{array}$ & $\begin{array}{c}1.66 \\
(0.82)\end{array}$ & $\begin{array}{l}1.79 \\
(2.16)\end{array}$ \\
\hline Liberal (after 1982) * Parental education: at least upper sec. & & & & & $\begin{array}{c}1.77 \\
(0.80)\end{array}$ & $\begin{array}{c}1.75 \\
(2.01)\end{array}$ & $\begin{array}{c}1.74 \\
(0.80)\end{array}$ & $\begin{array}{c}1.57 \\
(1.81)\end{array}$ \\
\hline Family centres & & & $\mathrm{x}$ & $\mathrm{x}$ & & & $\mathrm{x}$ & $\mathrm{x}$ \\
\hline Geographical macro-area & & & $\mathrm{x}$ & $\mathrm{x}$ & & & $\mathrm{x}$ & $\mathrm{x}$ \\
\hline$N$ & & 485 & & 483 & & 2,485 & & 483 \\
\hline $\mathrm{R} 2$ & & 12 & & .13 & & 0.12 & & 12 \\
\hline
\end{tabular}

Source: ISI 2006, authors' calculations. Weighted results. 
Table A4. Distribution of the independent and control variables for those who had not had sex at the time of

the interview and those who have missing values on the dependent variable.

\begin{tabular}{|c|c|c|}
\hline & $\begin{array}{l}\text { Never had sex at } \\
\text { the time of the } \\
\text { interview }\end{array}$ & $\begin{array}{l}\text { Missing on the y (1st } \\
\text { intercourse between } \\
\text { age } 10 \text { and } 24)\end{array}$ \\
\hline \multicolumn{3}{|l|}{ Gender } \\
\hline Men & 38.49 & 52.92 \\
\hline Women & 61.51 & 47.08 \\
\hline \multicolumn{3}{|l|}{ Parental education } \\
\hline at most lower sec. & 67.65 & 71.22 \\
\hline at least upper sec. & 31.39 & 27.58 \\
\hline missing & 0.96 & 1.2 \\
\hline \multicolumn{3}{|c|}{ Type of relationship with sexual partner } \\
\hline No relationship & & 20.53 \\
\hline Cohabiting/marriage & & 8.13 \\
\hline Partner & & 28.43 \\
\hline missing & & 42.91 \\
\hline \multicolumn{3}{|l|}{ Age at 1st sex } \\
\hline Min.10-Max.24, S.D. $=2.41$ & & 17 \\
\hline \multicolumn{3}{|l|}{ Geographical area } \\
\hline North-West & 20.79 & 26.56 \\
\hline North-East & 17.51 & 12.11 \\
\hline Center & 18.65 & 18.51 \\
\hline South and Islands & 43.05 & 42.83 \\
\hline \multicolumn{3}{|c|}{ Socio-historical context at age 15} \\
\hline Restrictive (before 1967) & 23.09 & \\
\hline Transformative (1967-1981) & 13.8 & \\
\hline Liberal (after 1982) & 63.1 & \\
\hline \multicolumn{3}{|c|}{ Context when $1^{\text {st }}$ intercourse occurred } \\
\hline Restrictive (before 1967) & & 26.97 \\
\hline Transformative (1967-1981) & & 26.4 \\
\hline Liberal (after 1982) & & 46.63 \\
\hline \multicolumn{3}{|c|}{ Own highest educational level attained } \\
\hline At most lower secondary & 58.01 & 61.34 \\
\hline At least upper secondary & 41.99 & 38.66 \\
\hline$N$. & 152 & 294 \\
\hline
\end{tabular}

Source: ISI 2006, authors' calculations. Weighted results. 


\section{Appendix B}

Starting from 1978, the Ministry of Justice and the Ministry of Health have had the duty to compile a report every year on the implementation of the law for the protection of maternity and for the voluntary termination of pregnancy (Law n. 194, paragraph 6, May 22nd) to the Parliament - the Relazione del Ministro della salute sulla attuazione della legge contenente norme per la tutela sociale della maternità e per l'interruzione volontaria di gravidanza - Legge 194/78). Until 1996, these reports contained information at the regional level on the number of abortions, the characteristics of the women who requested it, and the medical technicalities of the procedures, information on the number of centers for family planning and health available, and the number of medical doctors who refused to perform abortions due to moral concerns. The reports also include information on how many legal actions have been pursued against violators of the Law n. 194. This is also the reason why until then the report was compiled by both the Ministry of Justice and the Ministry of Health - and only by the latter from then on. The reports were retrieved on the regional level from the website https://storia.camera.it and http://www.salute.gov.it/portale/home.html. In this article we used the information on public family planning centres per 10.000 women aged 15 to 49 . This information is missing for the years 1978, 1979, 1980, and 1996. We manually imputed the missing information based on the previous (closest in time non-missing) year. For some years, only the total number of family planning centre was available. We therefore calculate the number of family planning centre per 10,000 women between age 15 and 49 using statistics on the number of women aged 15 to 49 provided by the Italian Statistical Institute (http://dati.istat.it/). The final result of the manual imputation is displayed in panel (b) Figure A1. A ready-to-use excel file with information on centers for family planning and health and medical doctors who did not perform abortion-related procedures by region between 1978 and 2017 is available at SowiDataNet|datorium: Gädecke M., Struffolino E., Zagel H. (2020), Family planning centres and doctors' conscientious objection in Italy: Historical series by region, Version 1.0.0. WZB Berlin Social Science Center. Dataset. - https://doi.org/10.7802/1.2031. 